\title{
What a neurologist should know about PET and SPECT functional imaging for Parkinsonism: a practical perspective
}

\author{
Stéphane Thobois, $\mathrm{MD}, \mathrm{PhD}^{1,2,3}$, Stéphane Prange, $\mathrm{MD}^{1,2}$, \\ Christian Scheiber, $\mathrm{MD}, \mathrm{PhD}^{4}$, Emmanuel Broussolle, $\mathrm{MD}, \mathrm{PhD}^{1,2,3}$
}

1-Univ Lyon, Institut des Sciences Cognitives Marc Jeannerod, CNRS, UMR 5229, F-69675

BRON, France

2-Hospices Civils de Lyon, Hôpital Neurologique Pierre Wertheimer, Service de Neurologie

C, Centre Expert Parkinson, Lyon, France

3-Univ Lyon, Faculté de Médecine et de Maïeutique Lyon Sud Charles Mérieux, F-69921

OULLINS, France

4-Hospices Civils de Lyon, Hôpital Neurologique Pierre Wertheimer, Service de Médecine

Nucléaire, Lyon, France

\section{Disclosures}

ST reports grants from Fondation pour la Recherche Medicale, France Parkinson, Fondation Neurodis; personal fees from UCB, Medtronic, Teva, Novartis, Aguettant; non-financial support from Zambon and Abbvie outside the submitted work.

SP reports grants from Fondation pour la Recherche Medicale and France Parkinson.

CS has nothing to disclose

EB reports grants from Medtronic, personal fees from Abbvie, UCB, and Aguettant

\section{Corresponding author}

Pr Stéphane Thobois, MD, $\mathrm{PhD}$

Hospices Civils de Lyon, Hôpital Neurologique Pierre Wertheimer, Service de Neurologie C, Centre Expert Parkinson, F-69677 BRON, France

E-mail : stephane.thobois@chu-lyon.fr

Tel : +33472357218

Fax : +33472357351 


\section{Abstract}

The diagnosis of a parkinsonian syndrome based on clinical criteria remains sometimes difficult, especially at disease onset. Brain or heart molecular imaging techniques (SPECT or PET) can provide a major help to improve and speed up diagnosis, influencing treatment strategies. Presynaptic dopaminergic imaging using either $\left[{ }^{18} \mathrm{~F}\right]$-Dopa PET or ${ }^{123} \mathrm{I}-2 \beta$ Carbomethoxy-3ß-(4-Iodophenyl)- N-(3-Fluoropropyl) Nortropane ([ $\left.{ }^{123} \mathrm{I}\right]$-Ioflupane)SPECT demonstrates or rules out the presence of a dopaminergic degenerative process. This allows to distinguish Parkinson's disease, Parkinson “plus" syndromes and dementia with Lewy bodies (reduced radiotracers binding) from essential tremor, psychogenic, post-neuroleptic or vascular parkinsonisms, dopa-responsive dystonia and Alzheimer's disease (normal radiotracers binding). For differential diagnosis between Parkinson's disease and Parkinson "plus" syndromes, brain molecular imaging with $\left[{ }^{18} \mathrm{~F}\right]$-Fluorodeoxyglucose $\left(\left[{ }^{18} \mathrm{~F}\right]-\mathrm{FDG}\right) \mathrm{PET}$ or ${ }^{99 \mathrm{~m}} \mathrm{Tc}-\mathrm{HMPAO}$ SPECT can provide useful information, whereas $\left[{ }^{18} \mathrm{~F}\right]$-Dopa PET or $\left[{ }^{123} \mathrm{I}\right]-$ Ioflupane does not separate these entities. Finally, sympathetic cardiac $\left[{ }^{123} \mathrm{I}\right]-$ Metaiodobenzylguanidine ([ $\left.\left.{ }^{123} \mathrm{I}\right]-\mathrm{MIBG}\right)$ scintigraphy or SPECT can help distinguishing Parkinson's disease and dementia with Lew bodies (decreased binding) from multiple system atrophy and progressive supranuclear palsy (normal binding). New radiotracers notably those targeting the pathological process itself such as Tau aggregates are under development and may provide interesting informations to delineate the different Parkinson "plus" syndromes. 


\section{Introduction}

The diagnosis of Parkinson's disease (PD), parkinsonian syndromes and many movement disorders relies mostly on clinical criteria. Such criteria and red flags are regularly updated in order to improve diagnosis accuracy but this one may remain challenging. This is notably the case for PD, progressive supranuclear palsy (PSP), multiple system atrophy (MSA), corticobasal degeneration (CBD) or dementia with Lewy bodies (DLB) [1-5]. Vascular, post neuroleptic or psychogenic parkinsonisms or atypical tremor may as well be difficult to distinguish from PD. Thus, despite efforts made by experts in the field to define detailed clinical criteria, the accuracy of clinical diagnosis remains insufficient and highly dependent on the level of expertise, experience of the clinician and duration of follow-up [6]. A recent meta-analysis showed that diagnosis accuracy for parkinsonism based on experts statement was of $79.6 \%$ for early diagnosis and $83.9 \%$ later, whereas non experts neurologists provide a good diagnosis in only $73.8 \%$ [6]. Diagnosis correctness clearly improves after 3.6 years of disease evolution [6]. The anatomopathological confirmation, very rarely available, remains the gold standard for diagnosis and reveals $25 \%$ errors in the diagnosis of PD provided by general neurologists [7]. In another clinicopathological series $26 \%$ of possible PD and $82 \%$ of probable PD had their diagnosis confirmed by neuropathology [8]. This last study also showed that the agreement between clinical and pathological diagnosis was much better beyond 5 years of disease evolution, which, again stresses the importance of follow-up duration (53 \% before 5 years disease evolution versus $85 \%$ after 5 years). For MSA and PSP clinicopathological studies have shown $30 \%$ diagnosis errors and up to $74 \%$ for CBD [9]. The sensitivity of the clinical diagnosis of PD, MSA and PSP were respectively of $89.2 \%$, $64.3 \%$ and $52.9 \%$ while the specificity was of $57.8 \%$ for PD, $99 \%$ for MSA and $100 \%$ for PSP [7]. In movement disorder units the sensitivity of the clinical diagnosis of PD, MSA and PSP were respectively of $91.1 \%, 88.2 \%$ and $84.2 \%$, showing the importance of clinical 
expertise [10]. Nevertheless, tools that improve diagnosis accuracy are mandatory because providing the right diagnosis as early as possible has important consequences in terms of prognosis and treatment choice [11]. As such, brain or heart molecular imaging using single photon emission computed tomography (SPECT) and positron emission tomography (PET), in combination with morphological brain imaging using MRI serve as powerful tools to investigate parkinsonian syndromes [12]. The aim of the present review is to give an overview on the role of available SPECT and PET molecular imaging tools in routine clinical practice nowadays and in the future.

\section{SPECT and PET functional imaging tools for neurologists in routine clinical practice}

\section{Dopaminergic system imaging}

Several SPECT or PET radiotracers are available for the clinicians. They assess the presynaptic dopaminergic innervation and confirm or not the presence of a dopaminergic degenerative process. The most commonly used is the $\left[{ }^{123} \mathrm{I}\right]$-Ioflupane SPECT or DATscan* that measures the dopamine transporter (DAT) availability. Many other DAT radiotracers exist but are not routinely accessible and will not be detailed here. Using PET, $\left[{ }^{18} \mathrm{~F}\right]$-Dopa is frequently used and measures the dopa-decarboxylase activity, which is another way to determine the integrity of presynaptic dopaminergic terminals [13]. In PD, the typical feature, notably early in the disease course, is an asymmetrical reduction of striatal binding with a rostrocaudal gradient and relative preservation of the caudate nucleus in comparison to the putamen [14]. Postsynaptic dopaminergic radiotracers such as $\left[{ }^{123} I\right]$ IBZM SPECT or $\left[{ }^{11} \mathrm{C}\right]-$ Raclopride PET also exist but are not used in routine practice.

A recent clinicopathological study in PD suggested that $\left[{ }^{123} \mathrm{I}\right]$-Ioflupane SPECT reflects DAT functioning rather than the number of dopaminergic neurons but others studies found a 
relationship between the uptake of this tracer and nigral dopaminergic neuronal density $[15,16]$. Furthermore, even if striatal $\left[{ }^{123} \mathrm{I}\right]$-Ioflupane uptake is well correlated with disease duration and severity on a population basis, important discrepancies often exist between the degree of reduction of tracer uptake and the severity of motor symptoms on an individual basis $[15,17]$. In other words, one can see patients with major DAT tracer uptake reduction but minor motor symptoms or the opposite. This could, at least partly, be explained by the fact that $\left[{ }^{123} \mathrm{I}\right]$-Ioflupane SPECT or other DAT radiotracers, because of a compensatory downregulation of DAT functioning, could overexpress the actual dopaminergic degeneration [18]. On the contrary a compensatory overactivity of dopa-decarboxylase could minimize $\left[{ }^{18} \mathrm{~F}\right]$-Dopa sensitivity to the degenerative process. This has to be theoretically taken into account but, in routine practice, both $\left[{ }^{18} \mathrm{~F}\right]$-Dopa PET and $\left[{ }^{123} \mathrm{I}\right]$-Ioflupane SPECT provide close information on the presence or absence of a dopaminergic nigrostriatal degeneration.

For $\left[{ }^{123} \mathrm{I}\right]$-Ioflupane SPECT there are some drug interactions that can affect the binding, but, this is, most of the time, a minor issue. More precisely all drugs that block the DAT must be stopped 1 to 2 weeks before DAT imaging, otherwise a complete drop in tracer binding will be observed (false positive) [19,20]. This concerns for example cocaine, methylphenidate, amphetamine or modafinil. Most antidepressant drugs, but also memantine and amantadine, have a minor effect on DAT tracer binding $(<15 \%)$ notably because $\left[{ }^{123} \mathrm{I}\right]$-Ioflupane is not fully selective for DAT and also labels serotonin transporter, which can be affected by concomitant intake of most antidepressant drugs. However this effect is limited and will not dramatically change the results, which allows to perform $\left[{ }^{123} \mathrm{I}\right]$-Ioflupane SPECT while patients still take these drugs $[19,20]$. Furthermore this is not an issue when visual assessment is performed but should be considered when performing semiquantitative analysis. On the other hand, dopaminergic treatments can be maintained. 
Analysis of $\left[{ }^{123} \mathrm{I}\right]$-Ioflupane SPECT or $\left[{ }^{18} \mathrm{~F}\right]$-Dopa PET is still frequently performed using simple visual inspection but many centers, nowadays, rather use semi-quantitative assessment in comparison with age-matched normal values, which is superior and advisable when the visual read is inconclusive. Both methods have excellent sensitivity (95-97\%) and specificity (97-100\%), meaning few false negatives and positives [21-23].

\section{Metabolic activity and brain perfusion imaging}

$\left[{ }^{18} \mathrm{~F}\right]$-Fluorodeoxyglucose $\left(\left[{ }^{18} \mathrm{~F}\right]\right.$-FDG) PET measures cerebral glucose metabolism, which reflects synaptic and neuronal activity [12]. $\left[{ }^{18} \mathrm{~F}\right]$-FDG PET sensitivity is above $75 \%$ and its specificity above $90 \%$ in differential diagnosis between PD and atypical parkinsonisms [24,25]. As $\left[{ }^{18} \mathrm{~F}\right]-\mathrm{FDG}$ PET is not available everywhere, variations of cerebral blood flow with SPECT and ${ }^{99 m}$ Tc-HMPAO can also provide useful information on local brain dysfunction [26]. Both tools are useful to distinguish PD from Parkinson "plus" syndromes but it is noteworthy that SPECT has much lower spatial resolution and global accuracy as compared with PET

\section{Sympathetic myocardiac innervation imaging}

$\left[{ }^{123} \mathrm{I}\right]$-Metaiodobenzylguanidine $\left(\left[{ }^{123} \mathrm{I}\right]-\mathrm{MIBG}\right)$ scintigraphy or SPECT provides information about peripheral sympathetic myocardial innervation and reveals the presence or absence of post-ganglionic sympathetic denervation that can help differentiating PD/DLB (decreased cardiac binding) from MSA and PSP (normal binding). [ $\left.{ }^{123} \mathrm{I}\right]-\mathrm{MIBG}$ scintigraphy or SPECT has a sensitivity comprised between $81-88 \%$ but below $70 \%$ at early stages of the disease, while its specificity is comprised between 77 and $89 \%$ [27-37]. 


\section{Indications and limits of functional imaging in routine clinical practice}

Neurologists are facing several important issues when seeing for the first time a patient with a suspicion of parkinsonian syndrome, falling into two main categories.

\section{Is there a dopaminergic degeneration?}

The presence or absence of presynaptic dopaminergic denervation is a key marker to decipher degenerative parkinsonian syndrome including PD, PSP, MSA, CBD and DLB from differential diagnoses without any dopaminergic degeneration.

\section{- Atypical tremor versus presynaptic parkinsonism}

This encompasses notably non parkinsonian tremor such as essential tremor that may sometimes have an unusual presentation (asymmetrical, doubt on a rest component, doubt on rigidity). In that situation $\left[{ }^{123} \mathrm{I}\right]$-Ioflupane SPECT is normal in more than $99 \%$ of the cases and subjects with normal $\left[{ }^{123} \mathrm{I}\right]$-Ioflupane SPECT never become parkinsonian (Fig 1). On the contrary patients with abnormal $\left[{ }^{123} \mathrm{I}\right]-$ Ioflupane SPECT but a clinical presentation not typical of PD will, in $65 \%$ of the cases, evolve to PD [38-40]. As mentioned previously, the specificity to rule out essential or non parkinsonian tremor is very high comprised between 97 and $100 \%[19,21]$. Therefore $\left[{ }^{123} \mathrm{I}\right]$-Ioflupane SPECT is an excellent tool to distinguish tremor from presynaptic parkinsonism whatever its subtype (PD, PSP, MSA...) and can correct clinically overdiagnosed PD [1-5; 39-42].

\section{- Presynaptic versus non presynaptic parkinsonism}

Non presynaptic parkinsonian syndromes designate psychogenic, post-neuroleptic and vascular (except those due to subtantia nigra or striatal stroke) parkinsonisms as well as idiopathic normal pressure hydrocephalus. Clinical presentation may be misleading and, sometimes, patients exhibit symptoms both related to neurodegenerative and non degenerative 
processes (for example, PD patients with a worsening of symptoms due to neuroleptics). The distinction between non presynaptic and presynaptic parkinsonian syndromes is of great importance to avoid prescription of useless and potentially deleterious antiparkinsonian drugs. This is, for instance, the case for psychotic patients exhibiting post-neuroleptic parkinsonism, for whom a dopaminergic treatment may lead to psychiatric side effects.

Patients with psychogenic or post-neuroleptic parkinsonism have a normal $\left[{ }^{123} \mathrm{I}\right]$-Ioflupane SPECT or $\left[{ }^{18} \mathrm{~F}\right]$-Dopa PET [43-47] (Fig 1). In drug-induced parkinsonism the presence of a reduced $\left[{ }^{123} \mathrm{I}\right]$-Ioflupane binding is the only predictor of a risk of parkinsonian symptoms progression and levodopa response, which is in favor of an underlying degenerative process [48]. The combined use of functional imaging and electrophysiology could further improve differential diagnosis between psychogenic and non psychogenic parkinsonism [43].

Vascular parkinsonism due to leucoaraiosis is characterized by a normal or a mild homogenous reduction of striatal $\left[{ }^{123} \mathrm{I}\right]$-Ioflupane SPECT or $\left[{ }^{18} \mathrm{~F}\right]$-Dopa PET uptake $[49,50]$ (Fig 1). On the contrary, parkinsonism induced by substantia nigra or striatum strokes are associated with a major ipsilateral reduction of $\left[{ }^{123} \mathrm{I}\right]$-Ioflupane uptake.

Idiopathic normal pressure hydrocephalus may sometimes associate parkinsonian signs to the classical triad. The few dopaminergic radiotracers studies having analyzed patients with idiopathic normal pressure hydrocephalus found, for some of them, no presynaptic dopaminergic denervation but decreased dopaminergic receptor availability [51], while others revealed a reduction of dopaminergic tracers uptake in less than half of the cases [52]. 


\section{- PD versus doparesponsive dystonia}

Doparesponsive dystonia (DRD) and young onset PD may be difficult to distinguish clinically at disease onset. However, contrary to PD, DRD does not progress and $\left.{ }^{[23} \mathrm{I}\right]$-Ioflupane SPECT or $\left[{ }^{18} \mathrm{~F}\right]$-Dopa PET are normal in DRD [53].

\section{- DLB versus Alzheimer disease}

Contrary to Alzheimer's disease, $\left[{ }^{123} \mathrm{I}\right]$-Ioflupane SPECT or $\left[{ }^{18} \mathrm{~F}\right]$-Dopa PET are abnormal in DLB [54-56]. $\left[{ }^{123} \mathrm{I}\right]-$ Ioflupane SPECT sensitivity and specificity to diagnose or rule out DLB in clinically and autopsy diagnosed cases are 78-87\% and 90-94\% [54-57].

\section{- The SWEDD issue}

Patients suspected of PD but without abnormalities on $\left[{ }^{123} \mathrm{I}\right]$-Ioflupane SPECT or $\left[{ }^{18} \mathrm{~F}\right]$-Dopa PET correspond to the so-called "Scan without evidence of dopaminergic degeneration" or SWEDD. This entity remains highly debated and some authors propose its complete abandon while others consider it as a particular but poorly understood entity [58]. It is very unlikely that SWEDD are due to a lack of sensitivity to detect dopaminergic denervation at early stage of PD as these functional imaging methods can detect dopaminergic denervation even before any clinical manifestations (and predict phenoconversion) and, obviously, more easily when motor symptoms start, which corresponds to a reduction of at least $60 \%$ dopaminergic innervation [59]. SWEDD represent a small percentage of patients suspected of PD or other degenerative parkinsonian syndromes. This percentage is variable and comprised between 1-2 $\%$ and $15 \%$ [60-62]. Furthermore the risk of conversion to PD at 5 years follow-up is mild and has been evaluated at $12.5 \%$ in a recent study [63]. These patients do not disclose the progression of dopaminergic lesions and motor signs usually seen in PD [41,64]. The most likely explanation is that SWEDD represent alternative diagnosis such as dystonic tremor, 
atypical tremor or non presynaptic parkinsonism (psychogenic, post-neuroleptic...). Errors in $\left[{ }^{123} \mathrm{I}\right]$-Ioflupane SPECT interpretation may also explain some cases of SWEDD. Indeed, in a recent study, only $0.2 \%$ of $\left[{ }^{123} \mathrm{I}\right]$-Ioflupane SPECT were finally considered as normal in patients suspected of PD after reinterpretation versus $2.4 \%$ in first instance [65].

\section{Parkinson's disease or Parkinson "plus" syndrome?}

\section{- Interest of presynaptic dopaminergic radiotracers}

Convergent evidence has demonstrated that, at an individual level, $\left[{ }^{123} \mathrm{I}\right]$-Ioflupane SPECT or $\left[{ }^{18} \mathrm{~F}\right]$-Dopa PET do not allow to differentiate PD and Parkinson "plus" syndromes [66-69]. (Fig 1). At the level of a population of patients, dopaminergic denervation is, however, more important and goes faster in Parkinson "plus" syndromes than in PD, and lesions are more homogeneous and less asymmetrical within the striatum in PSP and MSA compared to CBD and PD [70-72]. In addition, a relative preservation of dopaminergic terminals is observed in MSA with cerebellar features (MSAc) as well as a greater dopaminergic denervation in the caudate nucleus in PSP compared to MSAc and PD on the one hand and in MSA with predominant parkinsonism (MSAp) compared to MSAc on the other hand [73,74]. However these elements are not suitable to provide individual differential diagnosis in routine clinical practice. Furthermore, the anticipated greater asymmetry of dopaminergic degeneration in PD compared to MSA was not confirmed in autopsy-proven cases [69].

\section{- Interest of post-synaptic dopaminergic radiotracers}

Because of the extension of the degenerative process to post-synaptic dopaminergic receptors it is expected that post-synaptic dopaminergic radiotracers such as [123I]IBZM SPECT or $\left[{ }^{11} \mathrm{C}\right]$-Raclopride PET could help differentiating PD from Parkinson "plus" syndromes. Some 
studies have indeed shown a decrease of these radiotracers binding in the striatum in MSA and PSP compared to PD but the important impact of chronic dopaminergic drugs on dopaminergic receptors can, per se, affect their uptake [66,75-78]. More precisely, dopamine agonists and levodopa can induce an internalization of D1 and D2 dopaminergic receptors and, in turn, a decrease of dopaminergic postsynaptic radiotracers even in PD $[77,78]$. Thus these tools may be useful in untreated patients but not reliable in chronically treated patients, which represents the most common situation. Furthermore, these radiotracers are not available in many nuclear medicine centers. A comparison of sensitivity and specificity of [ ${ }^{123}$ I]IBZM SPECT and diffusion weighted MRI has, in addition, clearly shown a superiority of the MRI to differentiate patients with MSAp and PD.

\section{- Interest of studying brain metabolism and brain perfusion}

The use of perfusion SPECT allows correct discrimination between PD and Parkinson "plus" syndromes in $67 \%$ of the cases versus $58 \%$ for $\left[{ }^{123} \mathrm{I}\right]$-Ioflupane SPECT but the combination of both approaches leads to a much better diagnosis accuracy comprised between $82.4 \%$ and $86.1 \%$ [79,80]. ${ }^{99 \mathrm{~m}} \mathrm{Tc}-\mathrm{HMPAO}$ SPECT shows a bilateral fronto-parietal and thalamus hypoperfusion in CBD compared to PD [81]. In MSA compared to PD some studies showed surprisingly that the only difference between PD and MSA consisted in an occipital hypoperfusion in PD [82]. In PSP brain hypoperfusion is noted in the anterior cingulate and medial frontal cortex [83]

Another more interesting brain molecular imaging tool to achieve a good delineation between PD and Parkinson "plus" syndromes is the study of cerebral glucose metabolism using $\left[{ }^{18} \mathrm{~F}\right]-$ FDG PET. Several studies have shown that its sensitivity is above $75 \%$ and its specificity above $90 \%$ leading to diagnosis accuracy greater than $90 \%[24,25,84,85]$. More precisely PSP is characterized by frontal lobe, caudate and mesencephalon hypometabolism, while 
MSA is characterized by cerebellum, pons and putamen hypometabolism, CBD by lateralized fronto-parietal, thalamic and striatum hypometabolism and PD by relatively spared metabolism in the putamen, sensorimotor cortex and cerebellum [24,25,84-86] (Fig 2). In DLB, hypometabolism of the lateral occipital cortex is highly sensitive (93\%) while the relative preservation of the mid to posterior cingulate gyrus is very specific (100\%) $[84,85,87]$. However it has to be noted that the preservation of posterior cingulate cortex relative to the precuneus tends to disappear with disease progression in DLB [88]. For DLB diagnosis $\left[{ }^{18} \mathrm{~F}\right]$-FDG PET appears better than blood flow measure using ${ }^{99 \mathrm{~m}} \mathrm{Tc}-\mathrm{HMPAO}$ SPECT [89]. Finally, a recent report found a hypometabolism in caudate nucleus and putamen and preserved cortical metabolism in idiopathic normal pressure hydrocephalus [90].

\section{- Interest of studying sympathetic innervation}

$\left[{ }^{123} \mathrm{I}\right]-\mathrm{MIBG}$ scintigraphy or SPECT reveals the presence of postganglionic sympathetic myocardial denervation in PD as measured by a reduced heart/mediastinum uptake ratio, whereas this ratio is normal in MSA and PSP patients [27-37] (Fig 3). Meta-analyses have shown a sensitivity of $82-88 \%$ and a specificity of $77-89 \%$. In addition, there is a good correlation between MIBG scintigraphy or SPECT finding and the loss of subtantia nigra neuromelanin hypersignal in PD [91]. [123I]MIBG scintigraphy or SPECT may also be useful to differentiate PD and vascular parkinsonism [92]. Furthermore, [123I]MIBG scintigraphy or SPECT has now been acknowledged to better differentiate DLB form other dementia in comparison to $\left[{ }^{123} \mathrm{I}\right]$-Ioflupane SPECT that may be positive even in some forms of frontotemporal dementia [93]. It has however to be acknowledged that [123I]MIBG scintigraphy or SPECT may be abnormal in up to $30 \%$ of MSA patients $[28,29]$ and normal at disease onset in PD [94,95]. 


\section{Interest of future radiotracers}

Involvement of Tau protein in Alzheimer's disease, CBD and PSP explains the reason why recent attempts are made to develop PET Tau radiotracers. Several Tau ligands are under development notably the $\left[{ }^{8} \mathrm{~F}\right]-\mathrm{AV} 1451$ for PET. Increased Tau deposits in basal ganglia and mesencephalon in PSP vs AD and controls and increased Tau deposits in temporal cortex in $\mathrm{AD}$ vs PSP and controls have been demonstrated using $\left[{ }^{1} \mathrm{~F}\right]$-AV1451 PET [96]. Compared to PD and controls, $\left[{ }^{8} \mathrm{~F}\right]$-Flortaucipir discloses an increased binding in globus pallidus, midbrain, subthalamic nucleus (STN) and dentate nucleus in PSP patients [97]. The abnormalities of Tau tracer binding observed in subcortical regions in PSP compared to PD are not correlated to motor and cognitive manifestations severity and not associated with increased cortical Tau binding $[98,99]$. Furthermore age also induces Tau deposits, which has to be taken into account [99].

In CBD, using two different Tau tracer, the $\left[{ }^{8} \mathrm{~F}\right]-\mathrm{THK} 5351$ and the $\left[{ }^{8} \mathrm{~F}\right]-\mathrm{AV} 1451$, an asymmetrical increase of binding has been observed in the globus pallidus, and pre and postcentral gyrus as well as in the pyramidal tract $[98,100]$. The different topography of $\left[{ }^{8} \mathrm{~F}\right]-$ AV1451 increased binding may help differentiating PSP from CBD and AD [99].

These results seem promising but they are still preliminary and some controversies exist. Indeed a recent study did not find any difference of $\left[{ }^{8} \mathrm{~F}\right]-\mathrm{AV} 1451$ binding between PSP, PD and controls suggesting that this tracer may be more appropriate to detect paired helical filaments found in AD than straight Tau filaments observed in PSP [101]. Furthermore Tau pathology is also frequently observed using $\left[{ }^{8} \mathrm{~F}\right]-\mathrm{AV} 1451$ in cognitively impaired PD and DLB patients independently of amyloid burden, which sheds shadow on the specificity of this tracer and its capacity to distinguish PD from PSP or CBD [102]. In addition, there are some methodological issues that will need to be sorted out before using these radiotracers in 
routine. This concerns in particular off-target binding (including neuromelanin, melanin, blood components, MAO...) and the binding of some Tau radiotracers (PBB3) to $\alpha$-synuclein $[103,104]$. Finally a recent study combining $\left[{ }^{8} \mathrm{~F}\right]$-AV1451 PET and $\left[{ }^{1} \mathrm{C}\right]-$ Pittsburgh compound B (PIB) to measure amyloid deposits revealed that Tau deposit was not independent but related to $\beta$-amyloid status [105]. Overall, although interesting, these new radiotracers will need further analysis before being used in routine.

\section{Cost-effectiveness and impact on care of functional imaging}

Several studies have addressed the issue of the impact of $\left[{ }^{123} \mathrm{I}\right]$-Ioflupane SPECT on diagnosis and care and the cost-effectiveness of this technique. It has been shown that such tool can impact treatment strategy (initiation or withdrawal of dopamine replacement therapy) in 15 to $35 \%$ of the cases and improve the diagnosis or modify the follow-up of patients in $21 \%$ of the cases $[38,40]$. Therefore it is likely to be financially advantageous in clinically uncertain cases. In some rare situations it can even be helpful to perform a second $\left[{ }^{123} \mathrm{I}\right]$-Ioflupane SPECT as repeating such exam can help providing a diagnosis in $87.5 \%$ of patients with unconclusive diagnosis at baseline [106]. Nevertheless reimbursement level, scanner location, radiopharmaceutical costs, access and cost of clinical evaluation by expert neurologists and consequences of treatment choice are major factors that can differently affect, depending on the country and health system, the interest and cost-effectiveness of $\left[{ }^{123} \mathrm{I}\right]$-Ioflupane SPECT $[107,108]$. Importantly, the decision to prescribe or not a [ $\left.{ }^{123} \mathrm{I}\right]$-Ioflupane SPECT must only be taken after careful clinical investigation, as, whatever the stage of the disease, the accuracy of the diagnosis provided by $\left[{ }^{123} \mathrm{I}\right]$-Ioflupane SPECT and clinical expertise are very close [109,110]. 
A summary of the most important findings obtained with usual PET and SPECT radioradiotracers is provided in Table $\mathbf{1 .}$

\section{Conclusion}

PET and SPECT molecular imaging using radiotracers allowing the characterization of presynaptic dopaminergic innervation, brain metabolism or perfusion and peripheral sympathetic innervation provide very useful information in routine clinical practice to confirm or rule out clinically evoked diagnosis and to classify the different subtypes of parkinsonisms. Their use has to be limited to patients with challenging diagnosis, only after careful clinical examination and, usually, in combination with morphological imaging (MRI). It is of major importance that the acquisition and analysis of these examinations follow strict procedural guidelines in order to guarantee reliable informations [111,112]. In the future, new radiotracers will allow to study the pathological process itself (Tau or amyloid deposits) but methodological issues still exist and will have to be sorted out. The use of brain or heart molecular imaging techniques notably those permitting very early (even premotor) diagnosis will undoubtedly become of greater importance when disease modifying strategies will emerge. 


\section{Legends}

\section{Fig 1}

SPECT $\left[{ }^{123} \mathrm{I}\right]$-Ioflupane assessing presynaptic dopaminergic innervation in parkinsonian syndromes. A: Normal striatal radiotracer binding in post-neuroleptic parkinsonism (Post NL Park), vascular parkinsonism (VP), essential tremor (ET) and psychogenic parkinsonism (Psy Park); B: bilateral and asymmetrical reduction of striatal binding with rostrocaudal gradient in Parkinson's disease (PD) and corticobasal degeneration (CBD); C: bilateral reduction of striatal binding in dementia with Lewy bodies (DLB); D: bilateral reduction of striatal binding in progressive supranuclear palsy (PSP) and multiple system atrophy (MSA).

\section{Fig 2}

PET $\left[{ }^{18} \mathrm{~F}\right]-\mathrm{FDG}$ assessing brain glucose metabolism in degenerative parkinsonian syndromes. A: bilateral striatal hypermetabolism in Parkinson's disease (PD); B: bilateral striatal hypometabolism in multiple system atrophy (MSA); C: bilateral frontal hypometabolism in progressive supranuclear palsy (PSP); D: asymmetrical frontoparietal hypometabolism in corticobasal degeneration (CBD); E: bilateral occipital hypometabolism in dementia with Lewy bodies (DLB).

\section{Fig 3}

SPECT $\left[{ }^{123} \mathrm{I}\right]-\mathrm{MIBG}$ measuring postganglionic sympathetic innervation in parkinsonian syndromes. A: reduced heart/mediastinum uptake ratio in Parkinson's disease (PD) and dementia with Lewy bodies (DLB); B: normal heart/mediastinum uptake ratio in multiple system atrophy (MSA), progressive supranuclear palsy (PSP) and vascular parkinsonism (VP). 


\section{References}

1. Postuma RB, Berg D, Stern M, Poewe W, Olanow CW, Oertel W, Obeso J, Marek K, Litvan I, Lang AE, Halliday G, Goetz CG, Gasser T, Dubois B, Chan P, Bloem BR, Adler CH, Deuschl G. MDS clinical diagnostic criteria for Parkinson's disease. Mov Disord. 2015 Oct;30(12):1591-601

2. Höglinger GU, Respondek G, Stamelou M, Kurz C, Josephs KA, Lang AE, Mollenhauer B, Müller U, Nilsson C, Whitwell JL, Arzberger T, Englund E, Gelpi E, Giese A, Irwin DJ, Meissner WG, Pantelyat A, Rajput A, van Swieten JC, Troakes C, Antonini A, Bhatia KP, Bordelon Y, Compta Y, Corvol JC, Colosimo C, Dickson DW, Dodel R, Ferguson L, Grossman M, Kassubek J, Krismer F, Levin J, Lorenzl S, Morris HR, Nestor P, Oertel WH, Poewe W, Rabinovici G, Rowe JB, Schellenberg GD, Seppi K, van Eimeren T, Wenning GK, Boxer AL, Golbe LI, Litvan I; Movement Disorder Society-endorsed PSP Study Group. Clinical diagnosis of progressive supranuclear palsy: The movement disorder society criteria. Mov Disord. 2017 Jun;32(6):853-864.

3. Gilman S, Wenning GK, Low PA, Brooks DJ, Mathias CJ, Trojanowski JQ, Wood NW, Colosimo C, Dürr A, Fowler CJ, Kaufmann H, Klockgether T, Lees A, Poewe W, Quinn N, Revesz T, Robertson D, Sandroni P, Seppi K, Vidailhet M. Second consensus statement on the diagnosis of multiple system atrophy. Neurology. 2008 Aug 26;71(9):670-6.

4. Armstrong MJ, Litvan I, Lang AE, Bak TH, Bhatia KP, Borroni B, Boxer AL, Dickson DW, Grossman M, Hallett M, Josephs KA, Kertesz A, Lee SE, Miller BL, Reich SG, Riley DE, Tolosa E, Tröster AI, Vidailhet M, Weiner WJ. Criteria for the diagnosis of corticobasal degeneration. Neurology. 2013 Jan 29;80(5):496-503.

5. McKeith IG, Boeve BF, Dickson DW, Halliday G, Taylor JP, Weintraub D, Aarsland D, Galvin J, Attems J, Ballard CG, Bayston A, Beach TG, Blanc F, Bohnen N, Bonanni L, Bras J, Brundin P, Burn D, Chen-Plotkin A, Duda JE, El-Agnaf O, Feldman H, Ferman TJ, Ffytche D, Fujishiro H, Galasko D, Goldman JG, Gomperts SN, Graff-Radford NR, Honig LS, Iranzo A, Kantarci K, Kaufer D, Kukull W, Lee VMY, Leverenz JB, Lewis S, Lippa C, Lunde A, Masellis M, Masliah E, McLean P, Mollenhauer B, Montine TJ, Moreno E, Mori E, Murray M, O'Brien JT, Orimo S, Postuma RB, Ramaswamy S, Ross OA, Salmon DP, Singleton A, Taylor A, Thomas A, Tiraboschi P, Toledo JB, Trojanowski JQ, Tsuang D, Walker Z, Yamada M, Kosaka K. Diagnosis and management of dementia with Lewy bodies: Fourth consensus report of the DLB Consortium. Neurology. 2017 Jul 4;89(1):88-100.

6. Rizzo G, Copetti M, Arcuti S, Martino D, Fontana A, Logroscino G. Accuracy of clinical diagnosis of Parkinson disease: A systematic review and meta-analysis. Neurology. 2016 Feb 9;86(6):566-76.

7. Joutsa J, Gardberg M, Röyttä M, Kaasinen V. Diagnostic accuracy of parkinsonism syndromes by general neurologists. Parkinsonism Relat Disord. 2014 Aug;20(8):8404.

8. Adler CH, Beach TG, Hentz JG, Shill HA, Caviness JN, Driver-Dunckley E, Sabbagh MN, Sue LI, Jacobson SA, Belden CM, Dugger BN. Low clinical diagnostic accuracy of early vs advanced Parkinson disease: clinicopathologic study. Neurology. 2014 Jul 29;83(5):406-12.

9. Ling H, O'Sullivan SS, Holton JL, Revesz T, Massey LA, Williams DR, Paviour DC, Lees AJ. Does corticobasal degeneration exist? A clinicopathological re-evaluation. Brain. 2010 Jul;133(Pt 7):2045-57. 
10. Hughes AJ, Daniel SE, Kilford L, Lees AJ. Accuracy of clinical diagnosis of idiopathic Parkinson's disease: a clinico-pathological study of 100 cases. J Neurol Neurosurg Psychiatry. 1992 Mar;55(3):181-4.

11. O'Sullivan SS, Williams DR, Gallagher DA, Massey LA, Silveira-Moriyama L, Lees AJ. Nonmotor symptoms as presenting complaints in Parkinson's disease: a clinicopathological study. Mov Disord. 2008 Jan;23(1):101-6

12. Prange $S$, Hermier M, Danaila T, Laurencin C, Thobois S. Imagerie cérébrale dans les syndromes parkinsoniens. Presse Med. 2017 Mar;46(2 Pt 1):202-209.

13. Arena JE, Stoessl AJ. Optimizing diagnosis in Parkinson's disease: Radionuclide imaging. Parkinsonism Relat Disord. 2016 Jan;22 Suppl 1:S47-51.

14. Innis RB, Seibyl JP, Scanley BE, Laruelle M, Abi-Dargham A, Wallace E, Baldwin RM, Zea-Ponce Y, Zoghbi S, Wang S. Single photon emission computed tomographic imaging demonstrates loss of striatal dopaminetransporters in Parkinson disease. Proc Natl Acad Sci U S A. 1993 Dec 15;90(24):11965-9.

15. Saari L, Kivinen K, Gardberg M, Joutsa J, Noponen T, Kaasinen V. Dopamine transporter imaging does not predict the number of nigral neurons in Parkinson disease. Neurology. 2017 Apr 11;88(15):1461-1467.

16. Colloby SJ, McParland S, O'Brien JT, Attems J. Neuropathological correlates of dopaminergic imaging in Alzheimer's disease and Lewy body dementias. Brain. 2012 Sep;135(Pt 9):2798-808.

17. Colloby SJ, Williams ED, Burn DJ, Lloyd JJ, McKeith IG, O'Brien JT. Progression of dopaminergic degeneration in dementia with Lewy bodies and Parkinson's disease with and without dementia assessed using 123I-FP-CIT SPECT. Eur J Nucl Med Mol Imaging. 2005 Oct;32(10):1176-85

18. Ribeiro MJ, Vidailhet M, Loc'h C, Dupel C, Nguyen JP, Ponchant M, Dollé F, Peschanski M, Hantraye P, Cesaro P, Samson Y, Remy P. Dopaminergic function and dopamine transporter binding assessed with positron emission tomography in Parkinson disease. Arch Neurol. 2002 Apr;59(4):580-6.

19. Kägi G, Bhatia KP, Tolosa E. The role of DAT-SPECT in movement disorders. J Neurol Neurosurg Psychiatry. 2010 Jan;81(1):5-12.

20. Booij J, Kemp P. Dopamine transporter imaging with [(123)I]FP-CIT SPECT: potential effects of drugs. Eur J Nucl Med Mol Imaging. 2008 Feb;35(2):424-38.

21. Ottaviani S, Tinazzi M, Pasquin I, Nothdurfter W, Tomelleri G, Fincati E, Nordera G, Moretto G, Fiaschi A, Smania N, Giorgetti P, Antonini A. Comparative analysis of visual and semi-quantitative assessment of striatal [123I]FP-CIT-SPET binding in Parkinson's disease. Neurol Sci. 2006 Dec;27(6):397-401.

22. Benamer TS, Patterson J, Grosset DG, Booij J, de Bruin K, van Royen E, Speelman JD, Horstink MH, Sips HJ, Dierckx RA, Versijpt J, Decoo D, Van Der Linden C, Hadley DM, Doder M, Lees AJ, Costa DC, Gacinovic S, Oertel WH, Pogarell O, Hoeffken H, Joseph K, Tatsch K, Schwarz J, Ries V. Accurate differentiation of parkinsonism and essential tremor using visual assessment of [123I]-FP-CIT SPECT imaging: the [123I]-FP-CIT study group. Mov Disord. 2000 May;15(3):503-10.

23. Tossici-Bolt L, Dickson JC, Sera T, Booij J, Asenbaun-Nan S, Bagnara MC, Borght TV, Jonsson C, de Nijs R, Hesse S, Koulibaly PM, Akdemir UO, Koole M, Tatsch K, Varrone A. [123I]FP-CIT ENC-DAT normal database: the impact of the reconstruction and quantification methods. EJNMMI Phys. 2017 Dec;4(1):8.

24. Hellwig S, Amtage F, Kreft A, Buchert R, Winz OH, Vach W, Spehl TS, Rijntjes M, Hellwig B, Weiller C, Winkler C, Weber WA, Tüscher O, Meyer PT. $\left[{ }^{8}\right.$ F]FDGPET is superior to [ ${ }^{123}$ I]IBZM-SPECT for the differential diagnosis of parkinsonism. Neurology. 2012 Sep 25;79(13):1314-22. 
25. Eckert T, Barnes A, Dhawan V, Frucht S, Gordon MF, Feigin AS, Eidelberg D. FDG PET in the differential diagnosis of parkinsonian disorders. Neuroimage. 2005 Jul 1;26(3):912-21.

26. Eckert T, Van Laere K, Tang C, Lewis DE, Edwards C, Santens P, Eidelberg D. Quantification of Parkinson's disease-related network expression with ECD SPECT. Eur J Nucl Med Mol Imaging. 2007 Apr;34(4):496-501.

27. Novellino F, Arabia G, Bagnato A, Cascini GL, Salsone M, Nicoletti G, Messina D, Morelli M, Paglionico S, Giofrè L, Restuccia A, Torchia G, Condino F, Quattrone A. Combined use of DAT-SPECT and cardiac MIBG scintigraphy in mixed tremors. Mov Disord. 2009 Nov 15;24(15):2242-8.

28. Nagayama H, Hamamoto M, Ueda M, Nagashima J, Katayama Y. Reliability of MIBG myocardial scintigraphy in the diagnosis of Parkinson's disease. J Neurol Neurosurg Psychiatry. 2005 Feb;76(2):249-51.

29. Nagayama H, Ueda M, Yamazaki M, Nishiyama Y, Hamamoto M, Katayama Y. Abnormal cardiac [(123)I]-meta-iodobenzylguanidine uptake in multiple system atrophy. Mov Disord. 2010 Aug 15;25(11):1744-7.

30. Ishibashi K, Saito Y, Murayama S, Kanemaru K, Oda K, Ishiwata K, Mizusawa H, Ishii K. Validation of cardiac (123)I-MIBG scintigraphy in patients with Parkinson's disease who were diagnosed with dopamine PET. Eur J Nucl Med Mol Imaging. $2010 \mathrm{Jan} ; 37(1): 3-11$.

31. Kikuchi A, Baba T, Hasegawa T, Sugeno N, Konno M, Takeda A. Differentiating Parkinson's disease from multiple system atrophy by [123I] metaiodobenzylguanidine myocardial scintigraphy and olfactory test. Parkinsonism Relat Disord. 2011 Nov;17(9):698-700.

32. Orimo S, Suzuki M, Inaba A, Mizusawa H. 123I-MIBG myocardial scintigraphy for differentiating Parkinson's disease from other neurodegenerative parkinsonism: a systematic review and meta-analysis. Parkinsonism Relat Disord. 2012 Jun;18(5):494-500.

33. Treglia G, Cason E. Meta-analysis on MIBG scintigraphy in differential diagnosis between Parkinson's disease and neurodegenerative parkinsonism. Parkinsonism Relat Disord. 2012 Jul;18(6):805.

34. Behnke S, Hellwig D, Bürmann J, Runkel A, Farmakis G, Kirsch CM, Fassbender K, Becker G, Dillmann U, Spiegel J. Evaluation of transcranial sonographic findings and MIBG cardiac scintigraphy in the diagnosis of idiopathic Parkinson's disease. Parkinsonism Relat Disord. 2013 Nov;19(11):995-9.

35. Odagiri H, Baba T, Nishio Y, lizuka O, Matsuda M, Inoue K, Kikuchi A, Hasegawa T, Aoki M, Takeda A, Taki Y, Mori E. On the Utility of MIBG SPECT/CT in Evaluating Cardiac Sympathetic Dysfunction in Lewy Body Diseases. PLoS One. 2016 Apr 7;11(4):e0152746.

36. Niimi Y, Ito S, Murate K, Hirota S, Hikichi C, Ishikawa T, Maeda T, Nagao R, Shima S, Mizutani Y, Ueda A, Mutoh T. Usefulness of combining ${ }_{123}$ I-FP-CIT-SPECT striatal asymmetry index and cardiac ${ }_{123}$ I-metaiodobenzylguanidine scintigraphy examinations for diagnosis of parkinsonisms. J Neurol Sci. 2017 Jun 15;377:174-178.

37. Uyama N, Otsuka H, Shinya T, Otomi Y, Harada M, Sako W, Izumi Y, Kaji R, Watanabe Y, Takashi S, Kunikane Y. The utility of the combination of a SPECT study with [123I]-FP-CIT of dopamine transporters and [123I]-MIBG myocardial scintigraphy in differentiating Parkinson disease from other degenerative parkinsonian syndromes. Nucl Med Commun. 2017 Jun;38(6):487-492. 
38. Catafau AM, Tolosa E; DaTSCAN Clinically Uncertain Parkinsonian Syndromes Study Group. Impact of dopamine transporter SPECT using 123I-Ioflupane on diagnosis and management of patients with clinically uncertain Parkinsonian syndromes. Mov Disord. 2004 Oct;19(10):1175-82.

39. Ceravolo R, Antonini A, Volterrani D, Rossi C, Kiferle L, Frosini D, Lucetti C, Isaias IU, Benti R, Murri L, Bonuccelli U. Predictive value of nigrostriatal dysfunction in isolated tremor: a clinical and SPECT study. Mov Disord. 2008 Oct 30;23(14):204954.

40. Antonini A, Berto P, Lopatriello S, Tamma F, Annemans L, Chambers M. Costeffectiveness of 123I-FP-CIT SPECT in the differential diagnosis of essential tremor and Parkinson's disease in Italy. Mov Disord. 2008 Nov 15;23(15):2202-9.

41. Marshall VL, Reininger CB, Marquardt M, Patterson J, Hadley DM, Oertel WH, Benamer HT, Kemp P, Burn D, Tolosa E, Kulisevsky J, Cunha L, Costa D, Booij J, Tatsch K, Chaudhuri KR, Ulm G, Pogarell O, Höffken H, Gerstner A, Grosset DG. Parkinson's disease is overdiagnosed clinically at baseline in diagnostically uncertain cases: a 3-year European multicenter study with repeat [123I]FP-CIT SPECT. Mov Disord. 2009 Mar 15;24(4):500-8.

42. Bajaj N, Hauser RA, Grachev ID. Clinical utility of dopamine transporter single photon emission CT (DaT-SPECT) with (123I) ioflupane in diagnosis of parkinsonian syndromes. J Neurol Neurosurg Psychiatry. 2013 Nov;84(11):1288-95.

43. Benaderette S, Zanotti Fregonara P, Apartis E, Nguyen C, Trocello JM, Remy P, Devaux JY, Askienazy S, Vidailhet M. Psychogenic parkinsonism: a combination of clinical, electrophysiological, and [(123)I]-FP-CIT SPECT scan explorations improves diagnostic accuracy. Mov Disord. 2006 Mar;21(3):310-7.

44. Lorberboym M, Treves TA, Melamed E, Lampl Y, Hellmann M, Djaldetti R. [123I]FP/CIT SPECT imaging for distinguishing drug-induced parkinsonism from Parkinson's disease. Mov Disord. 2006 Apr;21(4):510-4.

45. Tinazzi M, Antonini A, Bovi T, Pasquin I, Steinmayr M, Moretto G, Fiaschi A, Ottaviani S. Clinical and [123I]FP-CIT SPET imaging follow-up in patients with drug-induced parkinsonism. J Neurol. 2009 Jun;256(6):910-5.

46. Felicio AC, Godeiro-Junior C, Moriyama TS, Shih MC, Hoexter MQ, Borges V, Silva SM, Aguiar Pde C, Andrade LA, Bressan RA, Ferraz HB. Degenerative parkinsonism in patients with psychogenic parkinsonism: A dopamine transporter imaging study. Clin Neurol Neurosurg. 2010 May;112(4):282-5.

47. Yomtoob J, Koloms K, Bega D. DAT-SPECT imaging in cases of drug-induced parkinsonism in a specialty movement disorders practice. Parkinsonism Relat Disord. 2018 May 5. pii: S1353-8020(18)30221-9. doi: 10.1016/j.parkreldis.2018.04.037. [Epub ahead of print]

48. Tinazzi M, Morgante F, Matinella A, Bovi T, Cannas A, Solla P, Marrosu F, Nicoletti A, Zappia M, Luca A, Di Stefano A, Morgante L, Pacchetti C, Minafra B, Sciarretta M, Dallocchio C, Rossi S, Ulivelli M, Ceravolo R, Frosini D, Cipriani A, Barbui C. Imaging of the dopamine transporter predicts pattern of disease progression and response to levodopa in patients with schizophrenia and parkinsonism: a 2-year follow-up multicenter study. Schizophr Res. 2014 Feb;152(2-3):344-9.

49. Gerschlager W, Bencsits G, Pirker W, Bloem BR, Asenbaum S, Prayer D, Zijlmans JC, Hoffmann M, Brücke T. [123I]beta-CIT SPECT distinguishes vascular parkinsonism from Parkinson's disease. Mov Disord. 2002 May;17(3):51823. 
50. Benítez-Rivero S, Marín-Oyaga VA, García-Solís D, Huertas-Fernández I, GarcíaGómez FJ, Jesús S, Cáceres MT, Carrillo F, Ortiz AM, Carballo M, Mir P. Clinical features and 123I-FP-CIT SPECT imaging in vascular parkinsonism and Parkinson's disease. J Neurol Neurosurg Psychiatry. 2013 Feb;84(2):122-9.

51. Ouchi Y, Nakayama T, Kanno T, Yoshikawa E, Shinke T, Torizuka T. In vivo presynaptic and postsynaptic striatal dopamine functions in idiopathic normal pressure hydrocephalus. J Cereb Blood Flow Metab. 2007 Apr;27(4):803-10.

52. Broggi M, Redaelli V, Tringali G, Restelli F, Romito L, Schiavolin S, Tagliavini F, Broggi G. Normal Pressure Hydrocephalus and Parkinsonism: Preliminary Data on Neurosurgical and Neurological Treatment. World Neurosurg. 2016 Jun;90:348-356.

53. Naumann M, Pirker W, Reiners K, Lange K, Becker G, Brücke T. [123I]beta-CIT single-photon emission tomography in DOPA-responsive dystonia. Mov Disord. 1997 May;12(3):448-51.

54. Costa DC, Walker Z, Walker RW, Fontes FR. Dementia with Lewy bodies versus Alzheimer's disease: role of dopamine transporter imaging. Mov Disord. 2003 Oct;18 Suppl 7:S34-8.

55. McKeith I, O'Brien J, Walker Z, Tatsch K, Booij J, Darcourt J, Padovani A, Giubbini R, Bonuccelli U, Volterrani D, Holmes C, Kemp P, Tabet N, Meyer I, Reininger C; DLB Study Group. Sensitivity and specificity of dopamine transporter imaging with 123I-FP-CIT SPECT in dementia with Lewy bodies: a phase III, multicentre study. Lancet Neurol. 2007 Apr;6(4):305-13.

56. Thomas AJ, Attems J, Colloby SJ, O'Brien JT, McKeith I, Walker R, Lee L, Burn D, Lett DJ, Walker Z. Autopsy validation of 123I-FP-CIT dopaminergic neuroimaging for the diagnosis of DLB. Neurology. 2017 Jan 17;88(3):276-283.

57. Papathanasiou N, Rondogianni P, Chroni P, Themistocleous M, Boviatsis E, Pedeli $\mathrm{X}$, Sakas D, Datseris I. Interobserver variability, and visual and quantitative parameters of (123)I-FP-CIT SPECT(DaTSCAN) studies. Ann Nucl Med. 2012 Apr;26(3):234-40.

58. Erro R, Schneider SA, Stamelou M, Quinn NP, Bhatia KP. What do patients with scans without evidence of dopaminergic deficit (SWEDD) have? New evidence and continuing controversies. J Neurol Neurosurg Psychiatry. 2016 Mar;87(3):319-23.

59. Iranzo A, Santamaría J, Valldeoriola F, Serradell M, Salamero M, Gaig C, NiñerolaBaizán A, Sánchez-Valle R, Lladó A, De Marzi R, Stefani A, Seppi K, Pavia J, Högl B, Poewe W, Tolosa E, Lomeña F. Dopamine transporter imaging deficit predicts early transition to synucleinopathy in idiopathic rapid eye movement sleep behavior disorder. Ann Neurol. 2017 Sep;82(3):419-428.

60. Nicastro N, Burkhard PR, Garibotto V. Scan without evidence of dopaminergic deficit (SWEDD) in degenerative parkinsonism and dementia with Lewy bodies: A prospective study. J Neurol Sci. 2018 Feb 15;385:17-21.

61. Fahn S, Oakes D, Shoulson I, Kieburtz K, Rudolph A, Lang A, Olanow CW, Tanner C, Marek K; Parkinson Study Group. Levodopa and the progression of Parkinson's disease. N Engl J Med. 2004 Dec 9;351(24):2498-508.

62. Parkinson Study Group. Dopamine transporter brain imaging to assess the effects of pramipexole vs levodopa on Parkinson disease progression. JAMA. 2002 Apr 3;287(13):1653-61.

63. Batla A, Erro R, Stamelou M, Schneider SA, Schwingenschuh P, Ganos C, Bhatia KP. Patients with scans without evidence of dopaminergic deficit: a long-term followup study. Mov Disord. 2014 Dec;29(14):1820-5.

64. Marek K, Seibyl J, Eberly S, Oakes D, Shoulson I, Lang AE, Hyson C, Jennings D; Parkinson Study Group PRECEPT Investigators. Longitudinal follow-up 
of SWEDD subjects in the PRECEPT Study. Neurology. 2014 May 20;82(20):17917.

65. Nicastro N, Garibotto V, Badoud S, Burkhard PR. Scan without evidence of dopaminergic deficit: A 10-year retrospective study. Parkinsonism Relat Disord. 2016 Oct; 31:53-58.

66. Kim YJ, Ichise M, Ballinger JR, Vines D, Erami SS, Tatschida T, Lang AE. Combination of dopamine transporter and D2 receptor SPECT in the diagnostic evaluation of PD, MSA, and PSP. Mov Disord. 2002 Mar;17(2):303-12.

67. Plotkin M, Amthauer H, Klaffke S, Kühn A, Lüdemann L, Arnold G, Wernecke KD, Kupsch A, Felix R, Venz S. Combined 123I-FP-CIT and 123I-IBZM SPECT for the diagnosis of parkinsonian syndromes: study on 72 patients. J Neural Transm (Vienna). 2005 May;112(5):677-92.

68. Scherfler C, Seppi K, Donnemiller E, Goebel G, Brenneis C, Virgolini I, Wenning GK, Poewe W. Voxel-wise analysis of [123I]beta-CIT SPECT differentiates the Parkinson variant of multiple system atrophy from idiopathic Parkinson's disease. Brain. $2005 \mathrm{Jul} ; 128(\mathrm{Pt} 7): 1605-12$.

69. Perju-Dumbrava LD, Kovacs GG, Pirker S, Jellinger K, Hoffmann M, Asenbaum S, Pirker W. Dopamine transporter imaging in autopsy-confirmed Parkinson's disease and multiple system atrophy. Mov Disord. 2012 Jan;27(1):65-71.

70. Cilia R, Rossi C, Frosini D, Volterrani D, Siri C, Pagni C, Benti R, Pezzoli G, Bonuccelli U, Antonini A, Ceravolo R. Dopamine Transporter SPECT Imaging in Corticobasal Syndrome. PLoS One. 2011 May 2;6(5):e18301.

71. Antonini A, Benti R, De Notaris R, Tesei S, Zecchinelli A, Sacilotto G, Meucci N, Canesi M, Mariani C, Pezzoli G, Gerundini P. 123I-Ioflupane/SPECT binding to striatal dopamine transporter (DAT) uptake in patients with Parkinson's disease, multiple system atrophy, and progressive supranuclear palsy. Neurol Sci. 2003 Oct;24(3):149-50.

72. Oh M, Kim JS, Kim JY, Shin KH, Park SH, Kim HO, Moon DH, Oh SJ, Chung SJ, Lee CS. Subregional patterns of preferential striatal dopamine transporter loss differ in Parkinson disease, progressive supranuclear palsy, and multiple-system atrophy. $\mathbf{J}$ Nucl Med. 2012 Mar;53(3):399-406.

73. Pirker W, Asenbaum S, Bencsits G, Prayer D, Gerschlager W, Deecke L, Brücke T. [123I]beta-CIT SPECT in multiple system atrophy, progressive supranuclear palsy, and corticobasal degeneration. Mov Disord. 2000 Nov;15(6):1158-67.

74. Joling M, Vriend C, van den Heuvel OA, Raijmakers PGHM, Jones PA, Berendse HW, Booij J. Analysis of Extrastriatal ${ }_{123}$ I-FP-CIT Binding Contributes to the Differential Diagnosis of Parkinsonian Diseases. J Nucl Med. 2017 Jul;58(7):11171123.

75. Seppi K, Schocke MF, Donnemiller E, Esterhammer R, Kremser C, Scherfler C, Diem A, Jaschke W, Wenning GK, Poewe W. Comparison of diffusion-weighted imaging and [123I]IBZM-SPECT for the differentiation of patients with the Parkinson variant of multiple system atrophy from those with Parkinson's disease. Mov Disord. 2004 Dec;19(12):1438-45.

76. Vlaar AM, de Nijs T, Kessels AG, Vreeling FW, Winogrodzka A, Mess WH, Tromp SC, van Kroonenburgh MJ, Weber WE. Diagnostic value of 123I-ioflupane and 123Iiodobenzamide SPECT scans in 248 patients with parkinsonian syndromes. Eur Neurol. 2008;59(5):258-66. 
77. Thobois S, Vingerhoets F, Fraix V, Xie-Brustolin J, Mollion H, Costes N, Mertens P, Benabid AL, Pollak P, Broussolle E. Role of dopaminergic treatment in dopamine receptor down-regulation in advanced Parkinson disease: a positron emission tomographic study. Arch Neurol. 2004 Nov;61(11):1705-9.

78. Politis $\mathrm{M}$, Wilson $\mathrm{H}, \mathrm{Wu} \mathrm{K}$, Brooks DJ, Piccini P. Chronic exposure to dopamine agonists affects the integrity of striatal $\mathrm{D}_{2}$ receptors in Parkinson's patients. Neuroimage Clin. 2017 Aug 24;16:455-460.

79. Van Laere K, Casteels C, De Ceuninck L, Vanbilloen B, Maes A, Mortelmans L, Vandenberghe W, Verbruggen A, Dom R. Dual-tracer dopamine transporter and perfusion SPECT in differential diagnosis of parkinsonism using template-based discriminant analysis. J Nucl Med. 2006 Mar;47(3):384-92.

80. Takaya S, Sawamoto N, Okada T, Okubo G, Nishida S, Togashi K, Fukuyama H, Takahashi R. Differential diagnosis of parkinsonian syndromes using dopamine transporter and perfusion SPECT. Parkinsonism Relat Disord. 2018 Feb;47:15-21.

81. Markus HS, Lees AJ, Lennox G, Marsden CD, Costa DC. Patterns of regional cerebral blood flow in corticobasal degeneration studied using HMPAO SPECT; comparison with Parkinson's disease and normal controls. Mov Disord. 1995 Mar;10(2):179-87

82. Song IU, Yoo I, Chung YA, Jeong J. The value of brain perfusion SPECT for differentiation between mildly symptomatic idiopathic Parkinson's disease and the Parkinson variant of multiple system atrophy. Nucl Med Commun. 2015 Oct;36(10):1049-54.

83. Varrone A, Pagani M, Salvatore E, Salmaso D, Sansone V, Amboni M, Nobili F, De Michele G, Filla A, Barone P, Pappatà S, Salvatore M. Identification by [99mTc]ECD SPECT of anterior cingulate hypoperfusion in progressive supranuclear palsy, in comparison with Parkinson's disease. Eur J Nucl Med Mol Imaging. 2007 Jul;34(7):1071-81

84. Walker Z, Gandolfo F, Orini S, Garibotto V, Agosta F, Arbizu J, Bouwman F, Drzezga A, Nestor P, Boccardi M, Altomare D, Festari C, Nobili F; EANM-EAN Task Force for the recommendation of FDG PET for Dementing Neurodegenerative Disorders. Clinical utility of FDG PET in Parkinson's disease and atypical parkinsonism associated with dementia. Eur J Nucl Med Mol Imaging. 2018 Jul;45(9):1534-1545.

85. Nobili F, Arbizu J, Bouwman F, Drzezga A, Agosta F, Nestor P, Walker Z, Boccardi M; EANM-EAN Task Force for the Prescription of FDG-PET for Dementing Neurodegenerative Disorders. European Association of Nuclear Medicine and European Academy of Neurology recommendations for the use of brain $18 \mathrm{~F}$ fluorodeoxyglucose positron emission tomography in neurodegenerative cognitive impairment and dementia: Delphi consensus. Eur J Neurol. 2018 Jun 22. doi: 10.1111/ene.13728. [Epub ahead of print]

86. Meyer PT, Frings L, Rücker G, Hellwig S. 18F-FDG PET in Parkinsonism: Differential Diagnosis and Evaluation of Cognitive Impairment. J Nucl Med. 2017 Dec;58(12):1888-1898.

87. Lim SM, Katsifis A, Villemagne VL, Best R, Jones G, Saling M, Bradshaw J, Merory J, Woodward M, Hopwood M, Rowe CC. The 18F-FDG PET cingulate island sign and comparison to 123I-beta-CIT SPECT for diagnosis of dementia with Lewy bodies. J Nucl Med. 2009 Oct;50(10):1638-45. 
88. Iizuka T, Iizuka R, Kameyama M. Cingulate island sign temporally changes in dementia with Lewy bodies. Sci Rep. 2017 Nov 7;7(1):14745.

89. O'Brien JT, Firbank MJ, Davison C, Barnett N, Bamford C, Donaldson C, Olsen K, Herholz K, Williams D, Lloyd J. 18F-FDG PET and perfusion SPECT in the diagnosis of Alzheimer and Lewy body dementias. J Nucl Med. 2014 Dec;55(12):1959-65.

90. Townley RA, Botha H, Graff-Radford J, Boeve BF, Petersen RC, Senjem ML, Knopman DS, Lowe V, Jack CR Jr, Jones DT. 18F-FDG PET-CT pattern in idiopathic normal pressure hydrocephalus. Neuroimage Clin. 2018 Feb 28;18:897902.

91. Miyoshi F, Ogawa T, Kitao SI, Kitayama M, Shinohara Y, Takasugi M, Fujii S, Kaminou T. Evaluation of Parkinson disease and Alzheimer disease with the use of neuromelanin MR imaging and (123)I-metaiodobenzylguanidine scintigraphy. AJNR Am J Neuroradiol. 2013 Nov-Dec;34(11):2113-8.

92. Navarro-Otano J, Gaig C, Muxi A, Lomeña F, Compta Y, Buongiorno MT, Martí MJ, Tolosa E, Valldeoriola F. 123I-MIBG cardiac uptake, smell identification and 123IFP-CIT SPECT in the differential diagnosis between vascular parkinsonism and Parkinson's disease. Parkinsonism Relat Disord. 2014 Feb;20(2):192-7.

93. Tiraboschi P, Corso A, Guerra UP, Nobili F, Piccardo A, Calcagni ML, Volterrani D, Cecchin D, Tettamanti M, Antelmi L, Vidale S, Sacco L, Merello M, Stefanini S, Micheli A, Vai P, Capitanio S, Gabanelli SV, Riva R, Pinto P, Biffi AM, Muscio C;

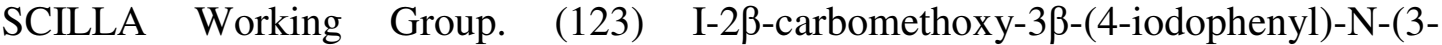
fluoropropyl) nortropane single photon emission computed tomography and (123) Imetaiodobenzylguanidine myocardial scintigraphy in differentiating dementia with lewy bodies from other dementias: A comparative study. Ann Neurol. 2016 Sep;80(3):368-78.

94. Südmeyer M, Antke C, Zizek T, Beu M, Nikolaus S, Wojtecki L, Schnitzler A, Müller HW. Diagnostic accuracy of combined FP-CIT, IBZM, and MIBG scintigraphy in the differential diagnosis of degenerative parkinsonism: a multidimensional statistical approach. J Nucl Med. 2011 May;52(5):733-40.

95. Kim JS, Park HE, Park IS, Oh YS, Ryu DW, Song IU, Jung YA, Yoo IR, Choi HS, Lee PH, Lee KS. Normal 'heart' in Parkinson's disease: is this a distinct clinical phenotype? Eur J Neurol. 2017 Feb;24(2):349-356.

96. Whitwell JL, Lowe VJ, Tosakulwong N, Weigand SD, Senjem ML, Schwarz CG, Spychalla AJ, Petersen RC, Jack CR Jr, Josephs KA. [18 F]AV-1451 tau positron emission tomography in progressive supranuclear palsy. Mov Disord. 2017 Jan;32(1):124-133.

97. Schonhaut DR, McMillan CT, Spina S, Dickerson BC, Siderowf A, Devous MD Sr, Tsai R, Winer J, Russell DS, Litvan I, Roberson ED, Seeley WW, Grinberg LT, Kramer JH, Miller BL, Pressman P, Nasrallah I, Baker SL, Gomperts SN, Johnson KA, Grossman M, Jagust WJ, Boxer AL, Rabinovici GD. 18 Fflortaucipir tau positron emission tomography distinguishes established progressive supranuclear palsy from controls and Parkinson disease: A multicenter study. Ann Neurol. 2017 Oct;82(4):622-634.

98. Smith R, Schain M, Nilsson C, Strandberg O, Olsson T, Hägerström D, Jögi J, Borroni E, Schöll M, Honer M, Hansson O. Increased basal ganglia binding of 18 F$\mathrm{AV}-1451$ in patients with progressive supranuclear palsy. Mov Disord. 2017 Jan;32(1):108-114. 
99. Cho H, Choi JY, Hwang MS, Lee SH, Ryu YH, Lee MS, Lyoo CH. Subcortical 18 FAV-1451 binding patterns in progressive supranuclear palsy. Mov Disord. 2017 Jan;32(1):134-140.

100. Kikuchi A, Okamura N, Hasegawa T, Harada R, Watanuki S, Funaki Y, Hiraoka K, Baba T, Sugeno N, Oshima R, Yoshida S, Kobayashi J, Ezura M, Kobayashi M, Tano O, Mugikura S, Iwata R, Ishiki A, Furukawa K, Arai H, Furumoto S, Tashiro M, Yanai K, Kudo Y, Takeda A, Aoki M. In vivo visualization of tau deposits in corticobasal syndrome by 18F-THK5351 PET. Neurology. 2016 Nov 29;87(22):23092316.

101. Coakeley S, Cho SS, Koshimori Y, Rusjan P, Harris M, Ghadery C, Kim J, Lang AE, Wilson A, Houle S, Strafella AP. Positron emission tomography imaging of tau pathology in progressive supranuclear palsy. J Cereb Blood Flow Metab. 2017 Sep;37(9):3150-3160.

102. Gomperts SN, Locascio JJ, Makaretz SJ, Schultz A, Caso C, Vasdev N, Sperling R, Growdon JH, Dickerson BC, Johnson K. Tau Positron Emission Tomographic Imaging in the Lewy Body Diseases. JAMA Neurol. 2016 Nov 1;73(11):1334-1341.

103. Marquié M, Verwer EE, Meltzer AC, Kim SJW, Agüero C, Gonzalez J, Makaretz SJ, Siao Tick Chong M, Ramanan P, Amaral AC, Normandin MD, Vanderburg CR, Gomperts SN, Johnson KA, Frosch MP, Gómez-Isla T. Lessons learned about [F18]-AV-1451 off-target binding from an autopsy-confirmed Parkinson's case. Acta Neuropathol Commun. 2017 Oct 19;5(1):75.

104. Perez-Soriano A, Arena JE, Dinelle K, Miao Q, McKenzie J, Neilson N, Puschmann A, Schaffer P, Shinotoh H, Smith-Forrester J, Shahinfard E, Vafai N, Wile D, Wszolek Z, Higuchi M, Sossi V, Stoessl AJ. PBB3 imaging in Parkinsonian disorders: Evidence for binding to tau and other proteins. Mov Disord. 2017 Jul;32(7):1016-1024.

105. Winer JR, Maass A, Pressman P, Stiver J, Schonhaut DR, Baker SL, Kramer J, Rabinovici GD, Jagust WJ. Associations Between Tau, $\beta$-Amyloid, and Cognition in Parkinson Disease. JAMA Neurol. 2018 Feb 1;75(2):227-235. doi: 10.1001/jamaneurol.2017.3713

106. Tolosa E, Borght TV, Moreno E; DaTSCAN Clinically Uncertain Parkinsonian Syndromes Study Group. Accuracy of DaTSCAN (123I-Ioflupane) SPECT in diagnosis of patients with clinically uncertain parkinsonism: 2-year follow-up of an open-label study. Mov Disord. 2007 Dec;22(16):2346-51.

107. Covington MF, McMillan NA, Kuo PH. Impact of Reimbursement Cuts on the Sustainability and Accessibility of Dopamine Transporter Imaging. J Am Coll Radiol. 2016 Sep;13(9):1039-43.

108. Stoessl AJ. Radionuclide scanning to diagnose Parkinson disease: is it costeffective? Nat Clin Pract Neurol. 2009 Jan;5(1):10-1

109. Dodel RC, Höffken H, Möller JC, Bornschein B, Klockgether T, Behr T, Oertel WH, Siebert U. Dopamine transporter imaging and SPECT in diagnostic work-up of Parkinson's disease: a decision-analytic approach. Mov Disord. 2003 Oct;18 Suppl 7:S52-62.

110. De la Fuente-Fernández R. Role of DaTSCAN and clinical diagnosis in Parkinson disease. Neurology. 2012 Mar 6;78(10):696-701.

111. Darcourt J, Booij J, Tatsch K, Varrone A, Vander Borght T, Kapucu OL, Någren K, Nobili F, Walker Z, Van Laere K. EANM procedure guidelines for brain neurotransmission SPECT using (123)I-labelled dopamine transporter ligands, version 2. Eur J Nucl Med Mol Imaging. 2010 Feb;37(2):443-50. 
112. Van Laere K, Varrone A, Booij J, Vander Borght T, Nobili F, Kapucu OL, Walker $Z$, Någren $K$, Tatsch K, Darcourt J. EANM procedure guidelines for brain neurotransmission SPECT/PET using dopamine D2 receptor ligands, version 2. Eur J Nucl Med Mol Imaging. 2010 Feb;37(2):434-42. 
Fig 1

SPECT [ [ ${ }^{123}$ I]-loflupane
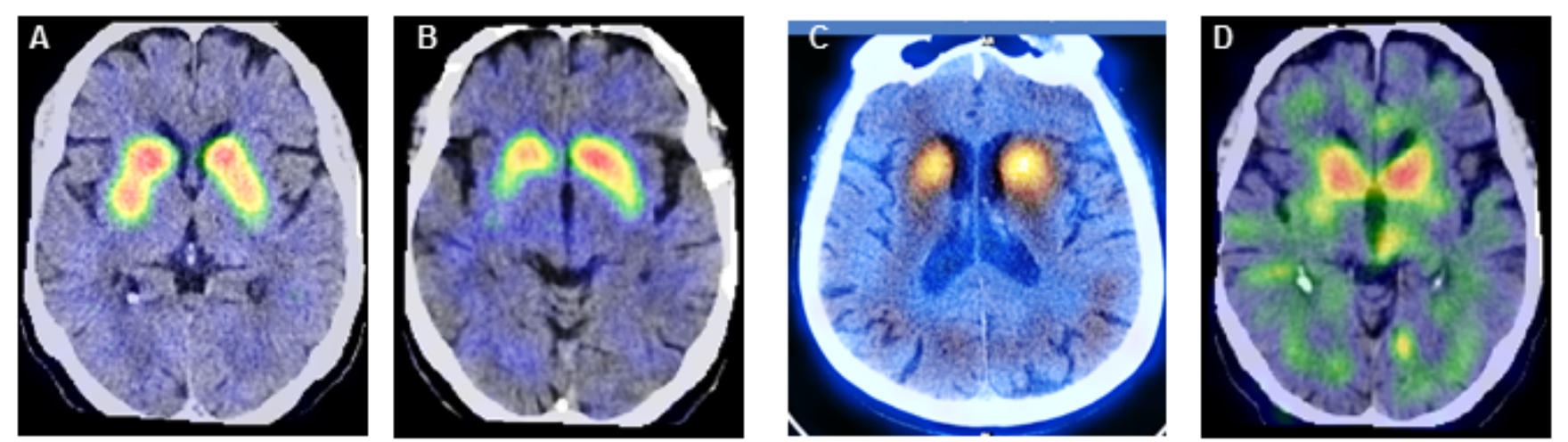

Post NL Park

VP

PD

DLB

CBD

PSP

MSA

Psy Park

DRD 
Fig 2

\section{PET $\left[{ }^{18}\right.$ F]-FDG}

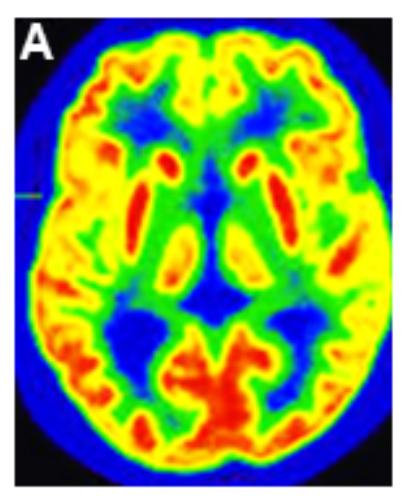

PD

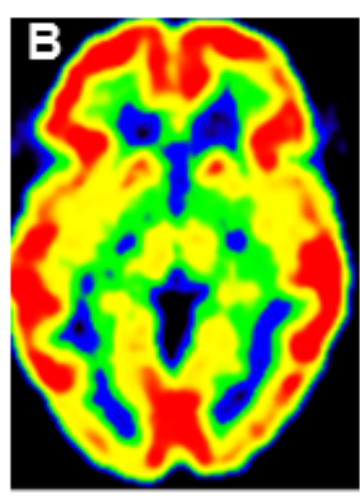

MSA

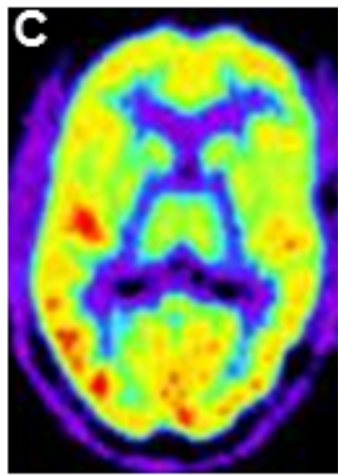

PSP

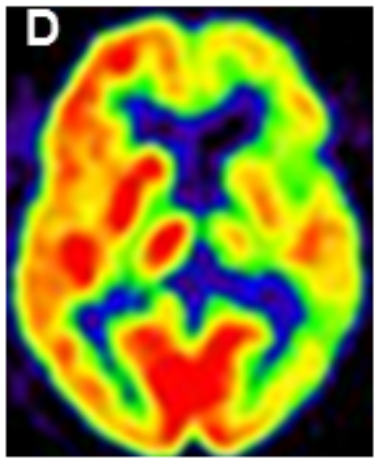

CBD

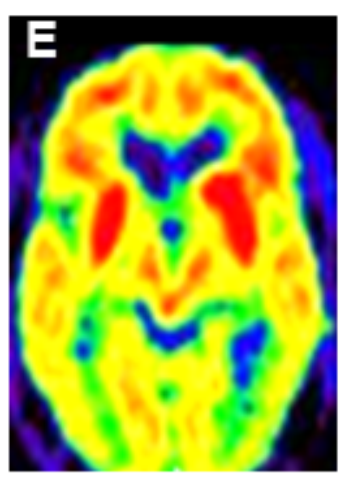

DLB 
Fig 3

\section{SPECT[ ${ }^{123}$ I]-MIBG}
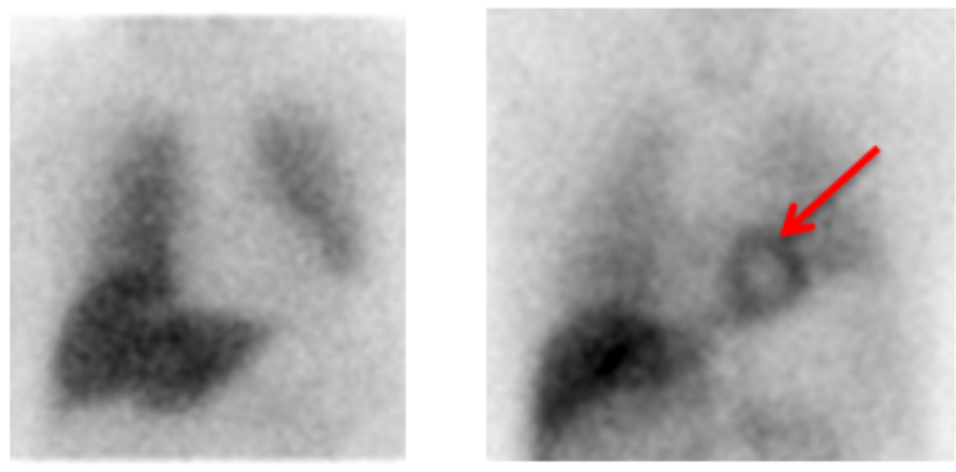

PD

MSA

PSP

VP 
Table 1: SPECT and PET findings in routine clinical practice

\begin{tabular}{|c|c|c|c|}
\hline Disease & $\begin{array}{l}{\left[{ }^{123} \mid\right] \text {-loflupane SPECT }} \\
\text { Dopaminergic innervation }\end{array}$ & $\begin{array}{l}{\left[{ }^{18} \text { F]-FDG PET }\right.} \\
\text { Brain metabolism }\end{array}$ & $\begin{array}{l}{\left[{ }^{123} \text { I]-MIBG cardiac SPECT }\right.} \\
\text { Sympathetic innervation }\end{array}$ \\
\hline PD & $\begin{array}{l}\text { Asymmetrical striatal reduction of binding } \\
\text { with rostro-caudal gradient }\end{array}$ & $\begin{array}{l}\text { Relative putamen, sensorimotor cortex } \\
\text { and cerebellum hypermetabolism }\end{array}$ & $\begin{array}{l}\text { Reduction of heart/mediastinum ratio } \\
\text { binding }\end{array}$ \\
\hline $\begin{array}{l}\text { Non presynaptic parkinsonism (VP, } \\
\text { postNL, psychogenic, NPH) } \\
\text { ET and DRD }\end{array}$ & $\begin{array}{l}\text { Normal } \\
\text { Sometimes slightly reduced in VP }\end{array}$ & $\begin{array}{l}\text { NPH: hypometabolism in caudate nucleus } \\
\text { and putamen and preserved cortical } \\
\text { metabolism } \\
\text { VP: Hypometabolism depending on the } \\
\text { topography of vascular lesions } \\
\text { ET, postNLand psychogenic Park: normal }\end{array}$ & Normal \\
\hline MSA & $\begin{array}{l}\text { Homogeneous and less asymmetrical } \\
\text { (unconstant) reduction of binding within } \\
\text { the striatum in MSA vs PD and CBD. } \\
\text { Greater abnormalities in MSAp versus } \\
\text { MSAC }\end{array}$ & $\begin{array}{l}\text { Cerebellum, pons and putamen } \\
\text { hypometabolism }\end{array}$ & $\begin{array}{l}\text { Normal in the majority of cases but } \\
\text { abnormal in } 30 \% \text { of the cases }\end{array}$ \\
\hline PSP & $\begin{array}{l}\text { Homogeneous and less asymmetrical } \\
\text { reduction of radiotracer uptake in the } \\
\text { striatum in PSP vs PD and CBD. Greater } \\
\text { abnormalities in PSP versus MSAc and PD }\end{array}$ & $\begin{array}{l}\text { Frontal lobe, caudate and mesencephalon } \\
\text { hypometabolism }\end{array}$ & Normal \\
\hline CBD & $\begin{array}{l}\text { Asymmetrical striatal reduction of } \\
\text { radiotracer uptake }\end{array}$ & $\begin{array}{l}\text { Lateralized fronto-parietal, thalamic and } \\
\text { striatal hypometabolism }\end{array}$ & Normal \\
\hline DLB & $\begin{array}{l}\text { Symetrical striatal reduction of radiotracer } \\
\text { uptake }\end{array}$ & $\begin{array}{l}\text { Lateral occipital cortex hypometabolism } \\
\text { and relative preservation of the mid to } \\
\text { posterior cingulate gyrus metabolism }\end{array}$ & $\begin{array}{l}\text { Reduction of heart/mediastinum ratio } \\
\text { binding }\end{array}$ \\
\hline
\end{tabular}

Abbreviations: PD: Parkinson's disease; VP: vascular parkinsonism; postNL: post neuroleptic parkinsonism; NPH: normal pressure hydrocephalus; ET: essential tremor; DRD: doparesponsive dystonia; MSA: multiple system atrophy; PSP: progressive supranuclear palsy; CBD: cortico-basal degeneration; DLB: dementia with Lewy Body; SPECT: single photon emision computed tomography; PET: positron emission tomography 